\title{
THE CAUCASIAN POLICY OF THE SELJUK STATE IN TURKISH HISTORIOGRAPHY
}

\author{
Bayramov M.J. \\ Associate professor \\ Lankaran State University
}

\section{КАВКАЗСКАЯ ПОЛИТИКА СЕЛЬДЖУКСКОГО ГОСУДАРСТВА В ТУРЕЦКОЙ ИСТОРИОГРАФИИ}

\author{
М.Дже.Байрамов \\ Ленкоранский государственный университет
}

Summary. The Caucasus region has always been in the center of attention of great powers, as it is located in a very favorable geographical area. The Caucasus was also of great importance to the Seljuk Turks, who established a state after a decisive victory over the Ghaznavids in the Battle of Dandanakan. As it is known, after the establishment of the Seljuk state by the Turks, their main policy was to advance to the west, to seize Anatolia and turn Anatolia into Turkish lands. The Caucasus region was the gateway to Anatolia. From this point of view, the Caucasus was of great military-strategic importance for the Seljuks. However, the study of the Caucasian policy of the Seljuk Turks began a little late in Turkish historiography. The article examines the research work written on this topic and determines the level of study of the topic in Turkish historiography.

Резюме. Кавказский регион всегда был в центре внимания великих держав, так как расположен в очень выгодном географическом районе. Кавказ также имел большое значение для турок-сельджуков, которые создали государство после решительной победы над Газневидами в битве при Данданакане. Как известно, после создания турками сельджукского государства их основной политикой было продвижение на запад, захват Анатолии и превращение Анатолии в турецкие земли. Кавказский регион был воротами в Анатолию. С этой точки зрения Кавказ имел большое военно-стратегическое значение для сельджуков. Однако изучение кавказской политики турок-сельджуков началось немного позднее в турецкой историографии. В статье рассматриваются исследовательские работы, написанные на эту тему, и определяется уровень изучения темы в турецкой историографии.

Key words: Caucasus, Seljuk state, historiography, Turkey, Alp Arslan, Melik Shah

Ключевые слова: Кавказ, сельджукское государство, историография, Турция, Алп Арслан, Мелик Шах

The Caucasus, which stretches from the Taman Peninsula in the northeast of the Black Sea to the Apsheron Peninsula in the west of the Caspian Sea, covering an area of about 379,880 km. The Caucasus Mountains divide the region into two parts, the North Caucasus and the South Caucasus. The North Caucasus is bordered by the Caspian Sea in the east, the Black Sea in the west, and the Caucasus Mountains in the south. The South Caucasus covers the present-day Republics of Azerbaijan, Armenia, Georgia, the Turkish cities of Arr, Kars and Artvin, and the territory up to the Iranian city of Tabriz $(1, \mathrm{p} .421)$.

The Caucasus has always been an important region in human history due to its natural and geographical location. Located at the crossroads of East and West, North and South, this region is a place where different civilizations, religions and peoples meet. Due to its geopolitical, geo-economics and geostrategic location, the Caucasus region has historically attracted the attention of major powers and has been influenced by the Sassanid, the Byzantine Empire and the Arab Caliphate, the Golden Horde, the Russian Empire and the European states.

Like many states, the Caucasus region was also very important for the Seljuk state. Turkish historian Ruhi Ersoy explains the importance of the Caucasus for the Seljuks in the words of historian Osman Turan written with reference to a Georgian source: "The Turks set up tents in these beautiful places from Tbilissi (Tbilisi) to Berdeo. Horses, camels, and sheep were innumerable. They live a wonderful life here; they hunted, had fun, rested, and lived without deprivation. They traded in the cities, raided Georgian and Armenian lands, and returned with captives and booty. In the spring they went out to the pastures. Turks came here from almost all over the world. No one, including the Sultan, could remove them from here and harm them $(2$, p.802; 3, p.38).

In this regard the Caucasus policy of the Great Seljuk State, the occupation Caucasus by the Seljuk, the relations of the Seljuk state with the Caucasian states are one of the topical issues in Turkish historiography. Although Turkish historians in the first half and middle of the twentieth century gave some space to this topic in their works, this problem was not a separate research work. Only in the 90 s of the XX century separate scientific works were devoted to the Caucasus policy of the Seljuk state and their relations with the countries of the Caucasus. It should be noted that most of the works written on this topic are scientific articles.

For the first time the well-known Turkish historian Mehmet Altay Koymen gave place to this topic in his book "Turkish history of the Seljuk period". Later professor Osman Turan in his work "History of the Seljuks and Turkish- 
Islamic Civilization" wrote in 1965, Ibrahim Kafesioglu in his book "History of the Seljuks" wrote in 1972 has investigated this topic.

Osman Turan devoted three chapter to this problem entitled "Alp Arslan's trip to Anatolian and Caucasus", "Alp Arslan's second Caucasus trip", "Melikshah's Caucasus trip, Anatolian and Syrian Issues" in his work "History of the Seljuks and Turkish-Islamic Civilization" written in 1965.

In the chapter called Alp Arslan's trips to Anatolia and the Caucasus the author writes that after the death of his uncle Togrul Bey, having defeated his enemies in the struggle for power his main foreign policy was to capture Anatolia and the Caucasus.

The researcher gave information about Alp Arslan's arrival with his army from Rey to Marand and then to Nakhchivan, here he left his son Malik Shah together with the vizier Nizamulmulk at the headquarters in Nakhchivan and instructed them to occupy the surrounding fortresses, his marching on Georgia and capturing many important cities and fortresses in Javakheti, Kartli and Kangarni.

The second half-chapter, entitled "Alp Arslan's Second Caucasus march".w In this section, the author describes the Sultan's second march to the Caucasus in 1068 due to the turmoil in the Caucasus during his visit to Kerman for quelling the revolt of his brother Kavurd and also gave information about seldjuks conqvest many cities and castles during 6 weeks, his occupying Tbilisi from the Georgian king and built a mosque here, and so on (3).

In general, although the work contains some material about the Seljuks Caucasus policy, as a whole is not devoted to this problem, only the work contains information about the Caucasus policy of Sultan Alp Arslan and Melikshah, and the information provided is superficial.

Professor Dr. Yashar Bedirkhan is one of the historians conducting research on this topic in Turkish historiography. His works: "The principles of political, economic and religious policy of the Great Seljuk Sultans in the Caucasus", "The struggle for political power between the Seljuks and Georgians in the Caucasus in the Middle Ages", "The Caucasian and Caucasian politics of the Seljuk State", "Relations of Turkmen Seljuks with Caucasus and Caucasus peoples", "The policy of the Sultans of the Seljuk empire against religious and political terrorism in the Middle East and the Caucasus" is devoted to this topic.

Yashar Bedirhan's main research work on this problem is his doctoral dissertation entitled "The Caucasus and the Caucasus Policy of the Great Seljuk State written in 1999". The dissertation is of great scientific importance not only in Turkish historiography, but also in the study of Seljuk Caucasian politics in world historiography. The dissertation covers the Caucasian policy of the Seljuk Turks from 1015 to the end of the Seljuk state in Iraq.

The research work is consist of 6 chapter entitled: "The first policies of the Seljuks towards the Caucasus", "The Seljuk sultans activities towards the Caucasus in the period of development and promotion (1040-1092) ", "The Seljuk sultans activities in the interregnum period and after that", "Caucasus in the period of Iran and Khorasan Seljuks", Principles of the political, economic, religious and cultural policies of the Seljuk state towards the Caucasus",The cultural situation of the Caucasus during the Seljuk period".

The first chapter, entitled "The First Seljuk Policies to the Caucasus", covers the travels of Chagri Bey to the Caucasus and Anatolia in 1015, and the activities of the Turkmens in the Caucasus, who separated from Togrul and Chagri Beys before the establishment of the Seljuk Empire.

In the second chapter named "The Seljuk sultans activities towards the Caucasus in the period of development and promotion1040-1092)" studied military and political activities of the great Seljuk Sultans Togrul Bey, Alp Arslan and Malik Shah in the Caucasus.

In the third chapter named "The Seljuk sultans activities in the interregnum period and after that" investigated the activities of Georgians and Armenians during the struggle for the throne in the Great Seljuk state after the death of Sultan Malikshah and the Caucasian policy of Muhammad Teper and Sultan Sencer were studied.

In the 4 chapter "Political activity of the Seljuk state towards the Caucasus during the Seljuk period of Iran and Khorasan" Caucasus policy of Iran and Khorasan Seljuks is bieng investigated. Information About the economic, religious and cultural policy of the Seljuk Turks towards the peoples of Caucasus was given in the 5 chapter entitled «The principles of the political, economic, religious and cultural policies of the Seljuk state towards the Caucasus. In the last chapter which called "The cultural situation of the Caucasus during the Seljuk period" the role of the Seljuks in the cultural development of the Muslim and non-Muslim population living within the imperial borders has been studied (5).

Thus, the researcher examines the political, economic, religious and cultural policy pursued by the Seljuk Turks towards the Caucasus and the peoples of the Caucasus for more than a century. For the first time, the Caucasian policy of the Seljuks was the subject of a comprehensive study.

One of the Y.Bedirhan's works on this subject is "The struggle for political power between the Seljuks and the Georgians in the Caucasus in the Middle Ages." The author states that the conquest of the Caucasus, as well as Georgia was of great vital importance for the Seljuks as it was for other great powers. Thus, the conquest of Georgia meant the removal of one of the biggest obstacles to the Seljuk occupations.

The article reflects the Caucasian policy of the Seljuk Turks from the time of Chagri Bey before the establishment of the state. Referring to historical sources, the author examines the struggles of the Seljuks and Georgians for political power 
in the Caucasus from 1018 to 1194. The article is one of the main research works on Seljuk policy in the Caucasus. The article is one of the main research works on Seljuk policy in the Caucasus (6).

One of the articles on Seljuk policy in the Caucasus written by Prof. Dr. Nebi Gumush entitled "The First Anatolian Selcuk-Georgian confrontation: The war of Pasins and its Consequences". It should be noted that this problem has not been paid much attention in Turkish historiography. Only the Turkish historian O.Turan made certain studies on this topic in his work "History of Turkey" "Sultan Suleyman-Shah II". One of the main reasons for this is the defeat of the Seljuk Turks in this battle.

As it is known, with the death of Sanjar, the youngest son of the great Seljuk sultan Malik Shah, in 1157, the Anatolian Seljuk state became completely independent. After the collapse of the great Seljuk state, the Anatolian Seljuk state tried to take its place and expand its position in the Caucasus. During the reign of Sultan Kilinc Arslan, the territory of the state expanded significantly. However, near the end of the reign of Kilinc Arslan II, the situation changed when he divided the territory of the state among his 11 sons. Soon, the struggle for political power between the boys intensified, which greatly weakened the state.

During this period, Georgia, was being ruled by Queen Tamara, became one of the most powerful states in the Caucasus and the Middle East. The expansion of Tamar's political activity in the Caucasus, which was of great importance for the Turks, could not but disturb the Seljuk sultan.

When Suleiman the magnificent came to power in 1196, the situation changed. After ascending the throne in Konya, Süleymanşah, who was trying to establish a union of the Anatolian Seljuk state, greatly expanded his territory by using internal divisions. After defeating the Armenians, he came to Erzurum in 1201 and captured it peacefully. In 1202 (Georgian historian N. Shengelia mentions this date in 1201) he advanced on Georgia. Researchers have different opinions about his trip to Georgia. However, it is truer that the war took place after 1202 and lasted until 1206.

In the article, the researcher writes that there are different opinions in historical sources about the cause of the Pasin war. Professor O. Turan states that the reason for this was the capture of Kars by the Georgians (7).

Turkish historian Erhan Ates, in his article "The Period of Queen Tamara (1184-1213) Georgian Foreign Policy and Reflections in the Region" explains such the reason for Ruknaddin Suleymanshah's visit to Georgia.

"The only force that could stand up to the Georgians during this period and stop their progress was the Turkish Seljuk state headed by Suleyman Ruknaddin Shah. The Turkish Seljuk state, meanwhile, was attacked by Georgians in the east and crusaders in the west. Therefore, the Turks living in Anatolia faced two dangers. If the Georgians were allowed to advance further both Anatolia and the Islamic world would be in danger. Rukneddin Suleymanshah moved to Erzurum in 1202 to put an end to the Georgian spread in the region".

In the article the researcher cites historical sources explain as such the reasons for the defeat of the Seljuks on the battle of the Pasins: Ibn Bibi and Unsi write that the Seljuk army was defeated in a great battle, while Aksaray wrote that the Georgians ambushed and defeated the Seljuk army. Osman Turan also explains the reason for the defeat of the Seljuks by their ambush by the Georgians. The reason of this he explains by Sultan Süleyman Shah careless actions, seeing his enemy weak (8).

Historian Erhan Ateş's article entitled "A Turning Point in the Seljuk-Georgian Struggles: The Battle of Didgori (1121) and Its Consequences" also covers this problem to some extent. The article is dedicated to the Battle of Didigori, a turning point in the ongoing struggle for political power in the Caucasus between the Seljuks and the Georgians. However, the article is of great importance for the study of Seljuk policy in the Caucasus.

Referring to the historical literature, the author emphasizes the importance of the Caucasus to the Seljuks with the following sentences. "Tuğrul Bey (1040-1063), who sat on the throne as the first Seljuk ruler after the establishment of the Great Seljuk State, first moved the center of his state from Nişabur to Rey in 1043. Then he tasked Ibrahim Yinal, son of Musa Yabgu, Hasan, the son of Khorasan ruler Davud Cagri, and some Seljuk princes, including Resul Tekin and Kutalmış, with the conquest of regions such as Azerbaijan, Arran, Armenia and Zencan”.

Stating that Sultan Alp Arslan, who succeeded Togrul Bey to the throne of the Seljuk state continued this policy the researcher gave information about his twice marching to the Caucasus in 1064 and 1068 with his son and his vizier, capturing many cities and fortresses, taking control of his reign, many Beyliks and emirs of Shaddadi ruled in many regions of Azerbaijan, including Tbilisi, such as Kartli, Chirac, Vanand, Nig, Gugarg, Arran and Ganja, Sultan Alp Arslan was named father of the conquest by occupying the town Ani, former capital of the Georgian king of the dynasty Bagarat IV and his marching to the Caucasus for the second time in 1068. Noting that his son Melikshah, who came to power after him, continued the Caucasian policy of the previous Seljuk rulers, the researcher was able to illuminate the Caucasus policy of the Great Seljuk State in the article.

One of the works written on this topic in the 90s of the XX century is an article by K. Ercilasun entitled "Seljuk Caucasus Policy". The author describes in detail the wars of the Great Seljuk sultans and princes for the conquest of the Caucasus since the time of Tugrul Bey in the section "Seljuk conquests of the Caucasus and their activities in the region" (1).

The researcher writes that there were many small states in the Caucasus as well as in Azerbaijan at that time. Noting that the largest of them was the Shirvanshah Kasrani state, the author notes that some of them supported the Byzantine 
state and others the Great Seljuk state. During this period, he writes, there is no force in the region that can protect its power alone.

Historian Darya Joshkon's article "Tugrul Bey's activities in the Caucasus in the context of the ideology of power" is also important in the study of Turkic politics in the Caucasus. However, only Sultan Togrul Bey's Caucasus policy was reflected in the article.

The researcher connects special interest of the Seljuk state, which taken an important place in the history of TurkishIslam, in the Caucasus with their policy of expansion to the west. Illuminating the marches of the Seljuks to the Caucasus and many of their political activities here, the author writes that this was due to the Seljuk ideology of world domination. Reporting that for the sake of the future and development of the Seljuk state Sultan Togrul Bey attached special importance to his visits to the Caucasus and made rapid progress in the Caucasus.

In the study of the Caucasian policy of the Seljuk Turks, the Turkish historian Professor Mehmet Ersan's article entitled "What does the Caucasus mean for the Seljuk Turks? is also noteworthy. The researcher states that the Caucasus played a key role in the strengthening and expansion of the Seljuk state. "After the death of Sultan Alp Arslan in 1072, the descendants of Kutalmish crossed the Caucasus and established a new Turkish state in the northwest of the peninsula. Prior to the establishment of the Seljuk state, Turkmen communities active in eastern and southeastern Anatolia, Syria, Iraq, and Palestine, and for the first time demonstrating the existence of the Seljuks in these regions, also came to Anatolia through the Caucasus. From this point of view, the Caucasus region was of transit importance for the Seljuk state.

One of the articles written on this subject is Savash Egilmez's article "The Caucasus Policy of the Great Seljuk Sultan Alp Arslan". The article reflects the accession of Alp Arslan to the throne, his first visit to the Caucasus and its reasons, the Seljuk occupation policy in Georgia, the occupation of Ani by Sultan Alp Arslan, the Sultan's second Caucasian policy.

The Turkish historian Mustafa Alijans's work "The Great Seljuks and the Caucasus" are also of great importance in this regard.

Thus, despite the fact that the Caucasus is of great importance for the Turkish Seljuk state, the "Caucasian policy of the Seljuk Turks" in Turkish historiography began a little late, in the late twentieth century and became more widespread in the first decades of the XXI century.

\section{List of used literature}

1. Ercilasun K. "Caucasian policy of Seljuks", Turkish culture, Year: XXXIII, number: 387, 1995

2. Ersoy R. Cultural geography of the Caucasus and the Turkic world. Eurasian International Studies Magazine, Archive, Volume 6, Issue 15, 2018

3. Turan O. Turkey in the time Seljuk. Boğaziçi publications, Istanbul. 1995.

4. Turan O. History of the Seljuks and Turkish-Islamic civilization. Istanbul, 1969

5. 5. Bedirhan Y. Caucasus and Caucasus policy of the Great Seljuk state. Doctoral dissertation, Konya, 1999

6. 6. Bedirhan Y. The struggle for political power between the Seljuks and the Georgians in the Caucasus in the middle Ages. Journal of Selçuklu University Institute of Social Sciences, 1983

7. Gumush N. The first Anatolian Seljuk-Georgian confrontation: the battle of Pasins and its consequences. Religious Studies Academic Research Journal, VI, 2006

8. Atesh E. Queen Tamara period (1184-1213) Georgian foreign policy and reflections in the region. Journal of Historical Reviews, C. XXXII / 2

9. 9. A Turning Point in the Seljuk-Georgian Struggles: The Battle of Didgori (1121) and its Consequences. Journal of Historical Research, Archive, Volume 35, Issue 60, 2016

10. Joshgun D. Tughril Beg's Activities in the Caucasus within the context of his goal of domination. Bayburt University Faculty of Human and Social Sciences Magazine, Archive, Volume 3, Issue 6, 2020

11. Ersan M. What does the Caucasus mean for the Turkish Seljuks. New Turkey, July-2015, number 72.

12. Egilmez S. Caucasus policy of the Great Seljuk Sultan Alp Arslan. New Turkey, July-2015, number 72. 